\title{
J. J. C Smart (1920-2012): Remembering Jack
}

\section{Monima Chadha $\cdot$ Purushottama Bilimoria $\cdot$ John Bigelow}

Published online: 17 April 2013

(C) Springer Science+Business Media Dordrecht 2013

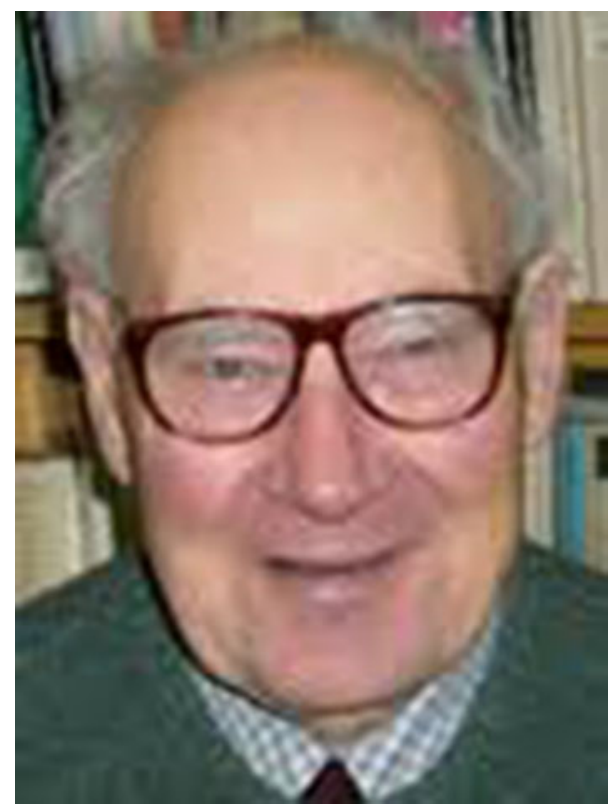

Born 16 September 1920, in Cambridge. Died: 6 October 2012, in Melbourne, Australia, aged 92. This memoir focuses on aspects of Professor J.J.C. Smart's philosophy and life that may interest the readers of Sophia.

Jack Smart was born into a Scottish family and educated at Leys school in Cambridge. His interest in cricket began in Leys school at an early age. In his

M. Chadha $(\bowtie) \cdot J$. Bigelow

Philosophy Section, School of Philosophical, Historical and International Studies, Monash University, Melbourne, Australia

e-mail: Monima.Chadha@arts.monash.edu.au

P. Bilimoria

SHAPS/Sophia, University of Melbourne, Melbourne, Australia e-mail: p.bilimoria@unimelb.edu.au 
younger years, Jack, with his father Prof. W.M. Smart, had the opportunity to have morning tea with the visiting Indian cricket team. This is perhaps the starting point of his interest in Indian cricket and in India more broadly. Jack began his University education at the University of Glasgow where he studied philosophy and mathematics. His undergraduate education was interrupted by service in the British Army. He became a member of the Royal Corps of Signals and worked towards English control of northeastern India in the Anglo-Burmese war. During this time Jack discovered Indian philosophy, which he brought back with him. He wrote an undergraduate thesis on Śankara (Samkara) and Bradley. Jack's view was sympathetic to begin with, and later, even when he was an avowed naturalist, he maintained that Śankara's metaphysics was impressive though absurd. While attached to an Indian regiment he learnt some Urdu and Punjabi to converse more readily with Indian troops and always greeted the many Indians he knew in Australia with an appropriate greeting in Punjabi or Urdu. Jack always had many interesting tales to tell from his time in India and had a soft spot for many philosophers and students who were Indian or had Indian origins.

In his diaries, Jack reminisces about his love of India and his brush with Indian Philosophy.

... So I shall here pass over my five years of army service, except to say that I was fortunate that four years of it were in India and Burma, especially as my time with 1 Med Rgt. Was in XV Ind Corps and 14th Army at a time when we were winning and the Japanese were having the worst time. I got to love India (and Burma too which was a happier country than India with a population of only 19 million and a high literacy rate - the villages we saw in Central Burma looked clean and salubrious). I even got to read books on Indian philosophy though they'd really be most easily got in UK - and liked to compare the Advaita Vedanta of Samkara and some of the Upanishads with the philosophy of my professor in Glasgow, and of F.H. Bradley. (Campbell out-Bradleyed Bradley with his book Scepticism and Construction in which he argued that Bradley should not have talked of degrees of truth since all propositions are infinitely far from the Absolute.) I concocted an argument against both which seemed good to me. Right at the end of my time in Burma when nothing much was doing I wrote a letter to Campbell using a packing case as a table and by the light of a kerosene lamp. He wrote me a gracious reply, defending his position. I now regret not keeping both letters. In India we were to a great extent sheltered from the awful poverty by being either in cantonments or camped out in the country. I have never returned to India since the war but have retained a keen interest in the country, reading books about it.

Jack arrived in Australia in 1950 when he was appointed to the Chair in Philosophy at the University of Adelaide, and from there he went to La Trobe University in Melbourne and then to the Australian National University in Canberra where he retired. Finally he settled in Melbourne and was Emeritus Professor at Monash University, when he died. He was a philosopher with a wide range of interests and made distinctive contributions to the study of ethics, philosophy of mind, metaphysics and philosophy of religion. Soon after his arrival in Australia Jack became a committed Quinean naturalist believing that reality is wholly natural: no God, no soul, no mysterious singularities, not even meanings or propositions. For Jack philosophy and science have the same subject 
matter, even though the methods are different. Śankara's Brahman was no exceptional singularity and was relegated to the realm of the absurd. But Jack maintained an interest in Indian philosophy and science primarily because his brother - 'Sri Ninian Smart' as Jack liked to refer to him - published important works on the subject. He respected Ninian's work and read all of it, even though he did not think much of it was true. For Jack, the guide to metaphysical truth is plausibility in the light of total science.

Ninian, for his part, had been stationed in Sri Lanka during the war where he encountered Buddhism, which led him to abandon his allegiance to his Oxford mentor, J.L. Austin, and to become an ecumenical Buddhist Episcopalian (as he would later describe himself), but eminently a philosopher of religion with deep leanings towards Indian and World Philosophy - all of which he wrote about prolifically. Jack, on the other hand, who was persuaded by his philosopher colleague Ullin Place's 'Mind-Brain Identity Theory' in the 1950s, abandoned his Anglican affiliations.

It is well known that Sophia had very close associations with Ninian (he was the international editorial advisor and regular contributor, in fact, from the very first issue in 1962) until his death in Lancaster in 2000. In an empathic telephone conversation Jack shared his grief over his younger brother's passing saying: 'Aha, Ninian was a great scholar and a marvellous man; he will be much missed'.

Jack was aware, from his cursory reading of Indian classics (in translation and books written by his brother, which he received graciously), that the Mādhyamika Buddhists had trumped Nyāya-Vaiśeșika ontology, epic moralism and Vedānta metaphysics with epistemology, rule-based ethics and naturalist psychology. Though Jack seemed not to have taken a deep interest in Buddhist philosophy or looked for naturalistic parallels there, in the way that more recent analytically trained philosophers and logicians (Jay Garfield, Purushottama Bilimoria, Graham Priest and Monima Chadha) have been engaged. But Jack always was interested in the work on Indian Philosophy done by Australian philosophers. It is no surprise then that Jack welcomes the very first volume of the Indian Journal of Philosophy in August 1959 with enthusiasm and takes care to note its Australasian flavour. Jack writes:

This new journal is a most welcome one. It promises to bring India right into the mainstream of world philosophy. No one with any acquaintance with ancient and mediaeval Indian systems of philosophy can fail to admire these great intellectual monuments, but unfortunately this very excellence has led Indian philosophers too much to look backwards towards their own philosophical heroes of the ancient and medieval times. ...Readers of the A.J.P may be interested in the slight Australasian flavour of this number of the journal. [The contributors in the first issue of this journal] Popper and Findlay have taught in New Zealand, Kamenka is from Sydney, Passmore we all know, one of the two book reviews is of Baier's book on ethics and the other is a compendium one of whose editors is a Melbourne graduate.

Through Jack we came to learn that back in 1957 the first ever East-West Philosophers' Conference in Australasia was held in Canberra, a 7-day closed workshop sponsored by UNESCO. Participants were brought out from India, Pakistan (known Oxbridge graduates) and New Zealand. Among them were Daya Krishna, 
Humayun Kabir and Sharif Hakim, and locally, A.N. Prior, J.L. Mackie, R.D. Bradley, A. and Q. Boyce Gibson, John Passmore, Annette Baier, A.K. Stout and Jack himself. In this paper entitled 'Philosophy and Religion' Jack puts forth his reconsidered view of religion in the light of Passmore's criticisms of his earlier lecture on Existence of God. Jack writes:

I do not deny the abstract possibility of supernaturalist reconstructions. Such a reconstruction might preserve orthodox Christianity against philosophical objections. Thus our reconstruction might leave place for the special faculty of intellectual intuition, and for a special sense of "necessary' such that 'necessary being' was not self-contradictory, the necessity of something existing being known by intuition. But who could accept such a rational reconstruction of language in the light of modern science? ...It now seems to me that the sort of reconstruction of language which would leave room for theology would have to make use of notions, such as those of the soul and intellectual intuition, which are scientifically quite unacceptable.

The proceedings were published in the AJP (Australasian Journal of Philosophy) the following year, edited by A.K. Stout, D.H. Munro and A. Boyce Gibson; other contributors were C.A. Campbell, Kai Nielsen and M. Arthadeva (a regular contributor based in India). It may surprise some to learn that analytical philosophy (in the Anglo-American fashion, not to speak of the Nyāya-Mīmāṃsā and Mādhyamaka variety) was well established in India in the colonial period before it got a footing in Australasia. It has never been forsaken in the subcontinent, though unlike the Australasian scenario, dialogue and 'comparative analytic' interaction with phenomenology, religious thinking and Continental fads have remained active.

Sometime back Jack had sent copies of a few journals of philosophy published in India that he had collected over the years to the Sophia office. In these pages and in a very early issue of AJP, Jack has couple of comparative articles of his own drawing on the Bhagavad-Gìtā metaphysics and philosophical theology. (That pursuit would record Jack as the first true-blue comparative philosopher in Australasia.) He ventured even further in the latter area, albeit from a critical standpoint. As part of the 'Great Debates in Philosophy', in the early 1990s, Jack engaged in a lengthy disquisition with the Scottish-Catholic philosopher, J.J. (John) Haldane on the question of 'Atheism and Theism' (published in 1996); it is a book as widely read as the one on 'Utilitarianism and Beyond' he edited with Bernard Williams and Amartya Sen.

To celebrate Ninian's contribution toward the resurrection of Sophia from its threatened demise, but also to applaud the 'very much an Aussie cricket-loving elder brother' of his, the journal brought out a special issue back in 1997, dubbed 'Smart Brothers'. Jack contributed a discussion article on Peter Forrest's book on Scientific Theism: God without the Supernatural. In that article Jack characteristically remarked that he was so persuaded by the mathematical and the ingenious scientific arguments Forrest had perspicuously woven through the book that he could come to believe in Forrest's God, that he could become a theist (again). Jack would not, however, forsake his belief in atheism, as Ninian would not his faith in 'non-theism' (or 'ana-theism', as he once subversively put it).

But there was a stark differential as well as split allegiances between the brothers when it came to cricket. Both brothers were great devotees of cricket, though Ninian 
would barrack for India on utilitarian (even negative utilitarian) grounds while Jack would barrack for Australia on precisely non-utilitarian grounds (philosophical predilections are reversed on the field, or as Jack put it at an AAP plenary 'I am not that kind of utilitarian'!). Jack was often seen with a pocket transistor glued to his ears and could rattle off distant scores; he liked perfect numbers. Ninian would for his part try and round up local Indians and Irishmen from the pubs, restaurants and faculty in Santa Barbara to put together the 'Bengal Rum' team to play an incomparable team of motley 'desis' (expats) from Los Angeles. 